\title{
Simulating oxygen intrusion into highly heterogeneous 2 fractured media using High Performance Computing
}

\author{
Paolo Trinchero • Jorge Molinero • \\ Hedieh Ebrahimi • Ignasi Puigdomenech • \\ Björn Gylling • Urban Svensson · Dirk \\ Bosbach • Guido Deissmann \\ Received: date / Accepted: date
}

\begin{abstract}
Fractured crystalline rocks are under consideration by several countries as host formations for high-level nuclear waste repositories. The redox evolution in these host rock formations is an important issue for the stability and safety of these disposal sites. If, for example, during a glaciation/deglaciation event, oxygen-rich glacial meltwater penetrates to the depth of the planned repository, some of the engineered barriers would be adversely affected. Moreover, oxidizing conditions would increase the solubility and mobility of many radionuclides. Reactive transport simulations, which are typically used to assess the redox buffering capacity of these host rock formations, are computationally demanding and, thus, calculations for e.g. the evaluation of oxygen penetration are usually carried out over simplified geometries and the heterogeneity of the site, both physical (e.g. variability in the groundwater flow field and the kinematic porosity) and mineralogical (e.g. variability in the abundance of $\mathrm{Fe}(\mathrm{II})$-bearing minerals), is usually represented in a simplified fashion. Here, we show how a recently developed numerical framework, combined with High Performance Computing (HPC) technologies, allows the full geometrical, physical and mineralogical complexity of the site under study to be efficiently included in reactive transport calculations. A synthetically-generated realistic three-dimensional fractured medium is used to assess oxygen penetration patterns and their dependency on both the hydrogeological conditions and the
\end{abstract}

Paolo Trinchero $\cdot$ Jorge Molinero $\cdot$ Hedieh Ebrahimi

AMPHOS 21 Consulting S.L., Passeig de Garcia i Faria, 49-51, 1-1, 08019 Barcelona, Spain Tel.: +34935830500

Fax: +34933075928

E-mail: paolo.trinchero@amphos21.com

Björn Gylling · Ignasi Puigdomenech

Swedish Nuclear Fuel and Waste Management Company, Box 250, 10124 Stockholm, Sweden

Urban Svensson

Computer-aided Fluid Engineering AB, Frankes väg 3, 37165 Lyckeby, Sweden

Dirk Bosbach · Guido Deissmann

Institute for Energy and Climate Research: Nuclear Waste Management and Reactor Safety (IEK-6) and JARA-HPC, Forschungszentrum Jülich GmbH, 52425 Jülich, Germany 
availability of $\mathrm{Fe}(\mathrm{II})$-bearing minerals. The results of the calculations point out the significant influence of both physical and mineralogical heterogeneity on the oxygen penetration patterns, thus highlighting the importance of a model parameterisation consistent with the site complexity.

Keywords Oxygen intrusion · Fractured media · High Performance Computing

\section{Introduction}

The intrusion of oxygenated water into anoxic and reducing fractured subsurface rocks is an issue of interest in safety assessment studies of deep geological disposal of nuclear waste. Given the high latitudes of some of the prospective disposal sites and the large time frames addressed in safety assessments for geological repositories, cyclic changes in climatic conditions (from temperate, to periglacial and eventually glacial) are expected. Studies based on natural analogues (Chapman et al., 1991; Romero et al., 1992; Cramer and Smellie, 1994; Cera et al., 2002; Akagawa et al., 2006) or analytical and numerical calculations (Glynn et al., 1999; Auqué et al., 2006; Guimerà et al., 2006; Sidborn, 2007; Sidborn and Neretnieks, 2008; Spiessl et al., 2008, 2009; Sidborn et al., 2010; MacQuarrie et al., 2010) have considered the possibility that during these glaciation/deglaciation cycles, oxygenated glacial meltwater could intrude to the depth of the planned repositories. This possibility is of primary concern for the safety assessment of these repositories as oxidizing conditions would (i) increase the solubility and mobility of many radionuclides (Glynn et al., 1999; Puigdomenech et al., 2001) and (ii) affect the long-term stability of some of the engineered barriers, such as the metallic (e.g. copper) canisters used to encapsulate the spent nuclear fuel or other nuclear wastes (Glynn et al., 1999; McMurry, 2000; Puigdomenech et al., 2001). Fe(II)-bearing reduced minerals (e.g. pyrite, chlorite, and biotite) present in the rock matrix or in fracture fillings may consume oxygen along the flow paths and thus buffer the reducing conditions currently observed at depth in candidate repository sites.

Most previous studies of oxygen intrusion are based on reactive transport modelling. Glynn et al. (1999) used a simplified mass balance calculation to estimate the buffering capacity of a single fracture-matrix system. In this model, oxygen is consumed in the rock matrix by biotite oxidation. The authors concluded that "biotite dissolution kinetics will not be sufficiently fast to prevent dissolved oxygen from reaching the repository depth of $500 \mathrm{~m}$ ". Spiessl et al. (2009) studied a similar system using a mechanistic model, which included advection processes along the fracture and diffusive processes and abiotic reactions in the rock matrix. The results of this model, which was solved using MIN3P (Mayer et al., 2002), substantially differ from those of Glynn et al. (1999), as dissolved $\mathrm{O}_{2}$ in the fracture reaches a quasi-steady profile after about 1,000 years, and the simulated $\mathrm{O}_{2}$ migration depth after 10,000 years is less than $100 \mathrm{~m}$. Spiessl et al. (2009) attributed these differences to the different conceptual models used in the two studies.

Guimerà et al. (2006) simulated the ingress of oxygenated water along a single fracture, in which oxygen was depleted by the oxidation of a fracture-filling mineral (annite, a Fe(II) mica). The numerical calculations were run out to 5,000 years using the geochemical code PHREEQC (Parkhurst and Appelo, 1999). The results of this model, which neglected the influence of the surrounding matrix, show that no oxygen reaches repository depth $(\approx 500 \mathrm{~m})$ during the considered time frame. 
Sidborn et al. (2010) used previously developed analytical solutions (Sidborn, 2007) and numerical calculations, carried out with PHAST (Parkhurst et al., 2004), to evaluate oxygen ingress in a "typical" fracture-matrix system of Forsmark (Sweden). The geochemical processes considered in these calculations are non-oxidative dissolution of biotite and homogeneous oxidation of dissolved ferrous ions. The authors observed that a pseudo-steady state oxygen profile is reached, where the steady-state oxygen penetration depth depends on the Fe(II) content of the rock and the hydrodynamic properties of the fracture. Close to the inlet boundary, oxygen penetrates approximately six millimeters into the rock matrix.

MacQuarrie et al. (2010) evaluated different models for oxygen penetration and consumption in a fractured crystalline rock system. The authors demonstrated that results depend dramatically on the underlying conceptual model. For instance, if the reducing capacity of $\mathrm{Fe}(\mathrm{II})$ minerals is neglected, significant concentrations of $\mathrm{O}_{2}$ may reach repository depth (i.e. $500 \mathrm{~m}$ depth) within a time frame of 10,000 years. However, in the "opposite extreme case", where chlorite is assumed to buffer oxygen migration along the fracture and biotite is considered to consume oxygen in the matrix, the penetration of $\mathrm{O}_{2}$ is modest (i.e. less than $20 \mathrm{~m}$ ).

All the numerical studies cited above (and, to the knowledge of the authors, all the reactive transport models that so far have assessed the issue of oxygen penetration in fractured media) are based on simplified geometrical representations of fractured crystalline rock systems. The reason for these simplifications lies in the numerical stiffness of this reactive transport problem (e.g. "It may be noted that the $2 D$ simulations in PHAST are extremely computationally demanding.[...] The simulation was stopped after 120 days due to the large CPU time [...]"; (Sidborn et al., 2010)) rather than in the lack of detailed information about the physical heterogeneity of the fractured medium. However, recent studies have demonstrated that similarly complex reactive transport problems can be efficiently solved using High Performance Computing (HPC) (e.g. Hammond et al., 2011, 2014; Beisman et al., 2015; Molinero et al., 2015; Trinchero et al., 2017a).

Besides physical heterogeneity, crystalline fractured rock systems are mineralogically heterogeneous (e.g. Posiva Oy, 2013; SKB, 2013). In some cases (Löfgren and Sidborn, 2009, 2010), the large amount of available information allows a statistical description of this heterogeneity. In all the aforementioned numerical studies, mineralogical heterogeneity is assessed by means of sensitivity analyses, where the mineral abundance or other related mineralogical parameters are varied and set to a new constant value in the whole model domain.

In this work, we show how a recently developed numerical framework (the interface between DarcyTools and PFLOTRAN, iDP (Molinero et al., 2015)) can be used to carry out site-scale reactive transport calculations of oxygen intrusion in fractured media. The main novelty of the proposed approach lies in the integration of heterogeneity, both physical (i.e. variability in the groundwater flow field and in the kinematic porosity based on an underlying Discrete Fracture Network, DFN, model) and mineralogical (e.g. variability in the abundance of $\mathrm{Fe}(\mathrm{II})$-bearing minerals), in a HPC simulation. Numerical experiments, based on a synthetically generated fractured medium, are used for process understanding. 


\section{Conceptual model}

The different models used in this work mimic the inflow of oxygenated water from the recharge area of a low permeable highly heterogeneous fractured rock medium. Oxygen is transported by downward vertical fluxes and is progressively consumed by abiotic reactions.

\subsection{Modelling approach}

The reactive transport calculations are carried out using iDP (Molinero et al., 2015), a numerical tool that provides an interface between two computer codes: DarcyTools (Svensson et al., 2010; Svensson and Ferry, 2014) and PFLOTRAN (Lichtner et al., 2013a,b).

DarcyTools is a finite-volume computer code for the simulation of flow and transport in subsurface heterogeneous media. An added value of DarcyTools is the capability of simulating flow and transport processes in fractured crystalline rocks. This is done by generating a stochastic DFN, whose hydraulic and transport properties (i.e. transmissivity and kinematic porosity) are then represented onto an underlying grid, which is where the flow and transport equations are actually solved. DarcyTools has been used in the last Swedish and Finnish safety analyses (i.e. SR-Site (SKB, 2011) and TURVA2012 (Posiva Oy, 2012)).

PFLOTRAN is a massively parallel finite-volume subsurface flow and reactive transport code.

By combining the two codes, iDP takes profit of the capability of DarcyTools to accurately solve flow in highly heterogeneous fractured media and the computational capacity of PFLOTRAN.

In the numerical exercises presented here, groundwater flow is first computed using DarcyTools. This calculation, which is computationally less expensive than the reactive transport simulations, is carried out in a powerful workstation. The computed Darcy's velocities and the DFN-derived kinematic porosities are retrieved by iDP and used as input for the PFLOTRAN simulations, which are solved in a supercomputer.

It is worthwhile noting that all the calculations are carried out over an Equivalent Porous Medium (ECP) whose parameterisation is directly derived from the underlying distribution of fractures and deformation zones (see section 2.2). Thus, the ECPM is a direct representation of the DFN and does not account for the influence of the rock matrix. However, matrix diffusion processes and the related reactions in the rock matrix could in principle be included in PFLOTRAN using a multi-continuum formulation (Lichtner, 2000).

\subsection{Groundwater flow and transport}

As mentioned in the Introduction, the numerical models presented in this and the next section are to be considered synthetic and, thus, their results are not representative of a specific real site. Yet, to provide these models with a realistic level of complexity, the set-up for groundwater flow is borrowed from an existing large scale hydrogeological model of the Forsmark area (Sweden), the designated 
site for a deep geological repository for spent nuclear fuel. Forsmark is located in northern Uppland within the municipality of Östhammar, about $120 \mathrm{~km}$ north of Stockholm. The host rock formation consists of crystalline bedrock that belongs to the Fennoscandian Shield.

The aforementioned model, which covers an area of $72 \mathrm{~km}^{2}$ approximately and extends to $584 \mathrm{~m}$ depth, was solved using DarcyTools. The model consists of 105,044,948 cells and mimics a steady-state groundwater flow field during temperate climatic conditions. The hydraulic properties of the system (i.e. hydraulic conductivity and porosity) are derived from an underlying Discrete Fracture Network (DFN) and represented onto an Equivalent Continuous Porous Medium (ECPM), using the approach described by Svensson (2001a,b); i.e. intersecting volumes between fractures and grid cell control volumes are computed and contributions from all intersecting fractures are added to the related parameters for each grid cell. The DFN and corresponding ECPM used in this work are equivalent to those described in Svensson and Follin (2010).

From a visual inspection of the hydraulic conductivity field (Figure 1) the presence of a complex fracture system, including single fractures and highly permeable zones, is evident. In the central part of the domain, that is where we focus our study, a finer refinement was used, with regular hexahedron elements of size $4 \mathrm{~m}$ x $4 \mathrm{~m} \times 2 \mathrm{~m}$. In the near-surface part of the domain, groundwater flow is strongly influenced by topography. The Forsmark site is relatively flat, with low reliefs that act as local recharge (downward fluxes) and low-lying areas of local discharge (upward fluxes) (Follin et al., 2014). Further details on the groundwater flow model can be found in Molinero et al. (2015).

The reactive transport calculations described in section 3 below, which are defined over sub-domains of the full site-scale hydrogeological model, are solved using PFLOTRAN. For each selected sub-domain, the steady-state groundwater velocity field (i.e. Darcy fluxes computed at cell sides) and the distribution of kinematic porosity are passed to PFLOTRAN via HDF5 files, which are generated by iDP. In the six sides of the selected sub-domains, a "Dirichlet_zero_gradient" transport boundary condition is defined, meaning that on fluid-inflow boundaries a solution is specified (i.e. Dirichlet boundary condition), whereas zero diffusive gradient is considered on outflow (i.e. only advective transport is considered on outflow). An oxidative groundwater type (see section 2.3) is assigned to the top side, whereas the other sides are linked to the initial ambient groundwater composition (see section 2.3).

\subsection{Geochemistry}

The geochemical model is taken from Sidborn et al. (2010). The main mineral involved in the calculations is biotite, which is assumed to be the source of dissolved ferrous iron. Its non-oxidative dissolution is represented using the following ratelaw:

$$
r_{\text {diss }}\left[\operatorname{mol}_{F e} / m^{2} s\right]=k_{F e, d i s s}\left(1-\frac{c_{F e}}{c_{F e, s o l}}\right)
$$

where $k_{F e, d i s s}$ is the maximum release rate of ferrous iron $\left(5.45 \cdot 10^{-13}\left[\mathrm{~mol}_{\mathrm{Fe}} / \mathrm{m}^{2} \mathrm{~s}\right]\right.$; (Sidborn et al., 2010)) and $c_{F e}$ is the aqueous iron concentration. In Sidborn et al. 

1961):

For $p H>4.5$, a widely used rate law for this reaction is (Stumm and Lee,

$$
r_{o x}\left[m_{F e} / L s\right]=k_{r} c_{F e} P_{O_{2}} c_{O H^{-}}^{2}
$$

(2010), $c_{F e, s o l}$ is assimilated to the iron solubility. However, this is not strictly correct as iron solubility depends on the solution composition and cannot be treated as a constant. Here, we denote $c_{F e, s o l}$ as the steady state Fe(II) concentration observed in the absence of an $\mathrm{O}_{2}$ perturbation. Field observations at the Forsmark site show that $c_{F e, s o l} \approx 1.8 \cdot 10^{-6}[\mathrm{~mol} / \mathrm{L}]$. This value is used in the calculations hereafter.

In Eq 1, $\left[\mathrm{m}^{2}\right]$ refers to the surface area of biotite. A high constant specific surface area $\left(\sim 10,000\left[\mathrm{~m}^{2} / \mathrm{m}_{b}^{3}\right]\right.$, being $m_{b}^{3}$ the bulk volume) is used in the calculations. With this high value, biotite can be considered at all times in equilibrium with the aqueous solution. This is a conceptual simplification as the mineral surface should depend on the amount of mineral in contact with the fracture groundwater. In a recent work (Trinchero et al., 2017b) the model presented here has been parameterised in a way consistent with field observations from Forsmark and an explicit relationship between the total amount of fracture surface and the mineral surface area is established.

The dissolved ferrous ions are oxidized by oxygen as follows:

$$
4 \mathrm{Fe}^{2+}+\mathrm{O}_{2}+4 \mathrm{H}^{+} \leftrightarrow 4 \mathrm{Fe}^{3+}+2 \mathrm{H}_{2} \mathrm{O}
$$

where $k_{r}$ is a homogeneous oxidation rate constant $\left(k_{r}=1.33 \cdot 10^{12}\left[1 / \mathrm{mol}^{2} \mathrm{~atm} \mathrm{~s}\right]\right)$, $\mathrm{P}_{\mathrm{O}_{2}}$ is the partial pressure of oxygen and $c_{\mathrm{OH}^{-}}$is the concentration of $\mathrm{OH}^{-}$.

As in Sidborn et al. (2010), the rate of oxidation of ferrous iron (Eq 3) has been simplified by assuming a constant $\mathrm{OH}^{-}$concentration equal to $1 \cdot 10^{-6} \mathrm{~mol} / \mathrm{L}$ (i.e. $p H \approx 8)$. With this simplification, Eq. 3 reduces to a second order kinetic reaction, which in PFLOTRAN can be easily defined using the "General_Reaction" card. The thermodynamic database used in the calculations is the Hanford database, which is included in the PFLOTRAN public distribution.

The groundwater types used in the model are taken from Salas et al. (2010).

The initial groundwater type is derived from a mix of the water types "Altered Meteoric" (solution 3 of appendix A1.8.1 of Salas et al. (2010)) and "Littorina" (solution 2 of appendix A1.8.1 of Salas et al. (2010)), with a resulting Cl concentration of $0.03 \mathrm{M}$ and a proportion of 0.84 and 0.16 , respectively. This groundwater has a $p e$ of -4.8 .

The infiltrating boundary water used in the calculations is the same reported in Salas et al. (2010) for glacial conditions (i.e. solution 4 of appendix A1.8.1).

Aggressive oxidizing conditions are simulated using an arbitrarily high oxygen content $\left(6.0 \cdot 10^{-3} \mathrm{~mol} / \mathrm{L}\right.$, which corresponds to $\left.200 \mathrm{mg} / \mathrm{L}\right)$, which results in a value of $p e$ around 13 . This oxygen content is higher than the value typically used for glacial meltwaters (i.e. $\approx 1.5 \cdot 10^{-3} \mathrm{~mol} / \mathrm{L}$, which corresponds to $48 \mathrm{mg} / \mathrm{L}$; (e.g. Sidborn et al., 2010; MacQuarrie et al., 2010)), and although there is no clear consensus on the maximum dissolved $\mathrm{O}_{2}$ levels, Glynn et al. (1999) state that "dissolved oxygen levels in glacial meltwaters beneath an ice sheet could exceed $45 \mathrm{mg} / \mathrm{L}$ ". Although lower $\mathrm{O}_{2}$ concentrations for the infiltrating waters would result 
in shorter intrusion distances, the general conclusions of this study would remain unchanged.

To keep track of the conservative transport patterns, a conservative tracer in unitary concentration is added to the boundary water.

\section{Reactive transport calculations}

The reactive transport calculations are carried out over two different sub-domains of the Forsmark hydrogeological model:

- Sub-domain 1 (50 kcells model): 50 x 49 x 20 cells (i.e. 49,000 cells). It corresponds to the blue box in Figure 2;

- Sub-domain 2 (4 Mcells model): 250 x 250 x 66 cells (i.e. 4,125,000 cells). It corresponds to the red box in Figure 2.

The grid cells are regular hexahedron elements of size $4 \mathrm{~m} \times 4 \mathrm{~m} \times 2 \mathrm{~m}$. As specified in section 2.2, Darcy fluxes and kinematic porosity are imported from the results of the DarcyTools groundwater flow calculation. The distribution of kinematic porosity is shown in Figure 3, for sub-domain 2 (similar heterogeneous distribution could be observed for the smaller sub-domain 1). Transport and reactions are assumed to take place in the ECPM only (i.e. matrix diffusion is not considered).

In the different set of calculations, two different "types" of models are considered. The "homogeneous" models denote cases where the spatial distribution of biotite is homogeneous. "Heterogeneous" calculations denote cases where the distribution of biotite is random, as detailed in sections 3.1 and 3.2, below. Both "homogeneous" and "heterogeneous" calculations use the same heterogenous Darcy fluxes and hydraulic properties.

\subsection{Sub-domain 1}

Sequential Indicator Simulations were carried out using SGeMS (Remy et al., 2009) to produce equi-probable realizations of biotite distribution. Ten different realizations were generated, with these categorigal values:

$-c_{1}$ : biotite present with initial volume fraction equal to 0.1 in $40 \%$ of the subdomain volume;

$-c_{2}$ : biotite present with initial volume fraction equal to 0.01 in $20 \%$ of the sub-domain volume;

- $c_{3}$ : biotite present with initial volume fraction equal to 0.001 in $10 \%$ of the sub-domain volume;

- $c_{4}$ : biotite absent in $30 \%$ of the sub-domain volume;

For these heterogeneous realizations, the resulting average volume fraction of biotite in the rock is around 0.042 ; i.e. about $4 \%$ of the total volume.

A spherical isotropic semivariogram with a range equal to $20 \mathrm{~m}$ was used to generate the random distribution. Two out of the ten considered realizations are shown in Figure 4. A homogeneous case, where the biotite volume fraction was set equal to 0.1 in the whole domain, was also run. 
The PFLOTRAN calculations were carried out in the supercomputer JUQUEEN of the Jülich Supercomputing Centre (Stephan and Docter, 2015) and span 1,000 years of simulation time. Each of the ten realizations was run using 1040 processor cores. Each processor has around 1 GB of memory, meaning that total memory used by each simulation was $1 \mathrm{~TB}$, approximately.

This sub-domain belongs to a recharge area of the regional hydrogeological model and, thus, groundwater velocities are mostly oriented in the vertical downward direction. The penetration of oxygen depends on possible preferential flow patterns, which in this model are related to the underlying discrete fracture network, and on the availability of dissolved ferrous ions. Dissolved iron, in turn, is released by biotite, if initially present and not yet completely dissolved.

The vertical extension of this model domain is limited (i.e. $40 \mathrm{~m}$ ) and this is reflected in relatively fast travel times (from the surface to the bottom of the domain). After 50 years, the tracer, which is added to the boundary water, has reached a considerable area of the bottom side whereas at the end of the simulation, unitary concentration is observed in the whole domain except for a very few localized spots where, due to the local flow circulation patterns, concentration is still lower (Figure 5). It is worthwhile noting that flow and conservative transport patterns are the same for all the considered realizations.

$p e$ is extremely sensitive to small variations in oxygen content and, thus, here we use it as a marker of oxygen. The spatial distribution of pe at 50 years and at the end of the simulation, computed for the homogeneous case and for two heterogeneous realizations (i.e. R1 and R8), is shown in Figure 6. The increase of $p e$ is modest in the homogeneous model while it is slightly more pronounced in the heterogeneous simulations (particularly, in realization 8; bottom left corner). It is worthwhile noting that the shape of the redox front of the homogeneous case is "uneven" due to the underlying heterogeneous flow patterns.

An indicator, denoted as relative footprint of the oxidizing plume, was defined and used to assess the results of the ten realizations. The relative footprint of the oxidizing plume is defined as the relative amount of cells of the bottom side of the sub-domain (or, of any considered control plane) with pe higher than a given threshold.

The relative footprint of the oxidizing plume is computed at the bottom side of the domain for all the considered realizations, using a threshold pe of 2.0 (i.e. $p e>2.0$; Figure 7). In the homogeneous calculation, pe at the bottom side of the domain is always below the threshold during the whole simulation time frame (i.e. 1,000 years). With this threshold, in the heterogeneous realizations (where biotite is randomly distributed and might be locally absent) the relative footprint of the oxidizing plume increases and asymptotically reaches a plateau value that ranges between 0.28 and 0.53 within the considered timeframe of 1,000 years.

Figure 8 provides information about the extension of oxygen penetration depth for the homogeneous case and the heterogeneous realization, R8. The grid cells that at 1,000 y of simulation time have an oxygen concentration higher than 1 . $10^{-7} \mathrm{~mol} / \mathrm{L}$ (i.e. concentration close to the detection limit) are shown and colored according to their oxygen concentration; whereas the rest of the cells are hidden. Dramatic differences between the homogeneous and the heterogeneous realization are evident. In the homogeneous case, oxygen penetration (i.e. $\mathrm{O}_{2}>1 \cdot 10^{-7} \mathrm{~mol} / \mathrm{L}$ ) is strongly buffered and limited to the first three cells in z-direction (i.e. $6 \mathrm{~m}$ depth). 
In the selected heterogeneous realization, the "oxygen plume" travels the whole domain depth (i.e. $40 \mathrm{~m}$ ).

The amount of biotite dissolution observed at the end of the simulations is modest (the results are not shown here for the sake of brevity).

\subsection{Sub-domain 2}

Given the large size of sub-domain 2, which implies high computational costs for the related reactive transport calculations, one single realization of hetereogenous biotite distribution was generated, using the same approach and parameters as for sub-domain 1 (see section 3.1). A "homogeneous" case, as for sub-domain 1, was not calculated. The resulting spatial distribution of the biotite volume fraction is shown in Figure 9.

The PFLOTRAN reactive transport calculation was carried out in JUQUEEN, using 1040 processor cores. The maximum wall-clock time of the simulation was set to $11 \mathrm{~h}$, meaning that approximately 12,000 h of supercomputing allocation time were consumed. With this maximum wall-clock time, the simulation run out to 70 years in time.

Figure 10 shows the grid cells of the upper layer of the sub-domain that have a negative vertical component of Darcy's velocity (i.e. downward fluxes - recharge areas), whereas the rest of the cells (i.e. upward fluxes - discharge areas) are blanked. Snapshots of tracer concentration, taken at simulation time 10 years and 70 years, are shown in Figure 11. At early times the tracer infiltrates from the recharge areas and is channeled along a network of preferential paths. At the end of the simulation, the tracer has already traveled the whole domain depth $(132 \mathrm{~m})$ along the most connected paths whereas other parts of the domain appear to be less connected to the surface boundary. At the end of the simulation, the tracer is also observed in most of the discharge areas, except for small spots that are influenced by local flow circulation patterns.

The evolution of $p e$ is shown in Figure 12. After a quick penetration of the redox perturbation front, a steady-state profile is reached, in which advective processes, which carry oxygen from the recharge area, are counterbalanced by geochemical reactions, which oxidize iron and consume oxygen. The development of a steady state oxygen profile was also observed by Sidborn et al. (2010) using the same geochemical model but a simplified single fracture-matrix system.

The penetration of the redox perturbation front is characterized by fingers, which are the result of the mutual interplay between preferential transport paths along transmissive and connected zones and the availability of biotite, which is responsible for the presence or absence of oxygen buffers (i.e. the ferrous ions). In the discharge areas, almost no redox perturbation is observed indicating that all the oxygen that in a hypothetical conservative case (i.e. without redox buffering reactions) would be observed in these discharge areas is actually consumed by the underlying buffering geochemical reaction. Interestingly, a similar finger-shaped redox transition zone was already observed in the natural analogue project Poço de Caldas, in Brazil (Romero et al., 1990, 1992). By mapping observations on the walls of the Osamu Utsumi mine and in boreholes, the authors concluded that " the redox front is very uneven and "fingering" is in evidence [...]" (Figure 13). The authors primarily attributed this evidence to channeling and preferential flow 
patterns, whereas the distribution of buffering minerals was not assessed in their study. However, the comparison between the model and the observations from Poço de Caldas should be considered as merely qualitative as the parameterisation of the model is based on sinthetic parameters. In a recent study (Trinchero et al., 2017b), the model presented here has been improved by providing a parameterisation of mineral surface area and volume fraction consistent with the underlying DFN. In this study a more exhaustive comparison with data Poço de Caldas is also provided.

The penetration of oxygen is shown in Figure 14. In the figure, only the grid cells that at 70 years of simulation time have an oxygen concentration higher than $1 \cdot 10^{-7} \mathrm{~mol} / \mathrm{L}$ (i.e. concentration close to the detection limit) are shown and colored according to their oxygen concentration; whereas the rest of the cells are hidden. With this range of concentration, the maximum oxygen penetration depth is $56 \mathrm{~m}$. Figure 15 shows the oxygen concentration computed in the upper layer of the model domain at 70 years of simulation time. In the same figure, those grid cells of the upper layer that do not contain biotite are shown. These results point out that oxygen is observed in relatively high concentrations $\left(\mathrm{O}_{2}>1 \cdot 10^{-7}\right.$ $\mathrm{mol} / \mathrm{L}$ ) only in the recharge areas while, as already observed for the $p e$, no oxygen is observed in the discharge areas. Very high oxygen concentrations $\left(\mathrm{O}_{2} \approx 1 \cdot 10^{-3}\right.$ $\mathrm{mol} / \mathrm{L}$ ) are observed only in those cells of the recharge area where biotite is absent. In the rest of the recharge area, most of the oxygen is already consumed in the uppermost layer of the domain.

The dissolution of biotite, expressed as whole rock volume fraction, is shown in Figure 16. Biotite is completely depleted only in the recharge area of the domain, in a few cells that are located in highly conductive zones. In the rest of the model, biotite depletion is modest and is only observed in the uppermost part of the domain.

When analyzing these results, it is also important to consider that the groundwater velocity field used in the reactive transport calculations is representative of temperate conditions. Typically, groundwater flow simulations of periods of glaciation/de-glaciation events would provide higher vertical hydraulic gradients (e.g. Vidstrand et al., 2010; Löfman and Karvonen, 2012) and this, in turn, would lead to higher oxygen penetration depths and to higher amounts of mineral consumption.

\section{Discussion and conclusions}

In this work we have shown how a recently developed HPC-based numerical framework, iDP, can be used to carry out continuum-based reactive transport calculations in complex heterogeneous sparsely fractured media. iDP interfaces two unique computer codes: DarcyTools, which is particularly designed to accurately represent flow in fractured media, and PFLOTRAN, a HPC reactive transport code with demonstrated scalability. To illustrate how the site-scale complexity (i.e. the physical heterogeneity due to the underlying fracture network and the mineralogical heterogeneity due to the uneven distribution of reactive mineral) can be efficiently included in reactive transport simulations, we have assessed a problem of interest for the safety analysis of repositories of spent nuclear fuel: the 
possible infiltration of oxygenated water into an anoxic and reducing fractured medium.

The results of synthetically based calculations lead to the following main conclusions:

- The penetration of oxygen is relatively fast until the redox front reaches a steady state at which the rate of $\mathrm{O}_{2}$ intrusion is balanced by the rate of iron mineral dissolution (biotite in this set of calculations). This steady state remains unaltered as long as the available biotite is not completely depleted. It may be noted that both the $\mathrm{O}_{2}$ concentration in the infiltrating waters and the reactive surface area would affect the location of the redox front.

- The oxygen penetration patterns and penetration depth are significantly influenced by both physical and mineralogical heterogeneity. For instance, when there are parts of the domain where the iron-bering mineral is absent, oxygen penetrates significantly more than when biotite is available everywhere.

- The interplay between physical and mineralogical heterogeneity lead to a finger shaped redox front. Qualitatively similar penetration patterns were observed in the natural analogue project site Poço de Caldas, in Brazil (Romero et al., 1990, 1992).

Given their illustrative purpose, the calculations presented here are based on a number of simplifying assumptions, which are briefly discussed below:

- The model accounts for fractures and deformation zones, which are represented in an Equivalent Porous Medium, but neglects the influence of the matrix. In these types of media and for the problem assessed here, matrix diffusion could be an important additional buffer for oxygen, particularly when iron-bearing minerals are present also in the matrix (Sidborn et al., 2010).

- Sub-grid heterogeneity is not accounted for. This could in principle be done using different alternative upscaling approaches (e.g. Malmström et al., 2000; Lichtner and Kang, 2007; Willmann et al., 2008; Miller et al., 2010).

- The parameterisation of geochemical reactions is not realistic. In a recent work (Trinchero et al., 2017b) the model presented here was improved by providing an explicit parameterisation of mineral surface area and mineral volume fraction based on the underlying DFN. In that work, a more exhaustive comparison with the observations from the natural analogue project site Poço de Caldas is also provided.

Acknowledgements PT, JM and HE thank the Swedish Nuclear Fuel and Waste Management Company (SKB) for the financial support. The authors also want to thank the PFLOTRAN development group for their help during the project. The authors gratefully acknowledge the computing time granted by the JARA-HPC Vergabegremium and provided on the JARA-HPC Partition part of the supercomputer JUQUEEN at Forschungszentrum Jülich.

\section{References}

F. Akagawa, H. Yoshida, S. Yogo, and K. Yamomoto. Redox front formation in fractured crystalline rock: an analogue of matrix diffusion in an oxidizing front along water-conducting fractures. Geochemistry: Exploration, Environment, Analysis, 6(1):49-56, 2006. 
L. Auqué, M. Gimeno, J. Gómez, I. Puigdomenech, J. Smellie, and E. Tullborg. Groundwater chemistry around a repository for spent nuclear fuel over a glacial cycle. TR-06-31, Svensk Kärnbränslehantering AB (SKB), 2006.

J. Beisman, R. Maxwell, A. Navarre-Sitchler, C. I. Steefel, and S. Molins. ParCrunchFlow: an efficient, parallel reactive transport simulation tool for physically and chemically heterogeneous saturated subsurface environments. Computational Geosciences, 19(2):403-422, 2015.

E. Cera, L. Ahonen, C. Rollin, J. Bruno, J. Kaija, and R. Blomqvist. Redox processes at the Palmottu uranium deposit. the Palmottu Natural Analogue Project. Y50/99/19, Geological Survey of Finland, 2002.

N. Chapman, I. McKinley, M. Shea, and J. Smellie. The Poços de Caldas project: Summary and implications for radioactive waste management. TR-90-24, Svensk Kärnbränslehantering AB (SKB), Stockholm, Sweden, 1991.

J. Cramer and J. Smellie. Final report of the AECL/SKB Cigar Lake analog study. TR-94-04, Svensk Kärnbränslehantering AB (SKB), Stockholm, Sweden, 1994.

S. Follin, L. Hartley, I. Rhén, P. Jackson, S. Joyce, D. Roberts, and B. Swift. A methodology to constrain the parameters of a hydrogeological discrete fracture network model for sparsely fractured crystalline rock, exemplified by data from the proposed high-level nuclear waste repository site at Forsmark, Sweden. Hydrogeology Journal, 22(2):313-331, 2014.

P. Glynn, C. Voss, and A. Provost. Deep penetration of oxygenated meltwaters from warm based ice sheets into the fennoscandian shield. In Use of hydrogeochemical information in testing groundwater flow models, pages pp.201-241. Workshop organized by NEA and SKB - Borgholm, Sweden, September 13,1997, 1999.

J. Guimerà, L. Duro, and A. Delos. Changes in groundwater composition as a consequence of deglaciation. R-06-105, Svensk Kärnbränslehantering AB (SKB), 2006.

G. Hammond, P. Lichtner, and M. Rockhold. Stochastic simulation of uranium migration at the Hanford 300 area. Journal of Contaminant Hydrology, 120: 115-128, 2011.

G. Hammond, P. Lichtner, and R. Mills. Evaluating the performance of parallel subsurface simulators: An illustrative example with PFLOTRAN. Water Resources Research, 50(1):208-228, 2014.

P. Lichtner, G. Hammond, C. Lu, S. Karra, G. Bisht, B. Andre, R. Mills, and J. Kumar. PFLOTRAN Web page, 2013a. http://www.pflotran.org.

P. Lichtner, G. E. Hammond, C. Lu, S. Karra, G. Bisht, B. Andre, R. Mills, and J. Kumar. PFLOTRAN user manual. Technical report, 2013b.

P. C. Lichtner. Critique of dual continuum formulations of multicomponent reactive transport in fractured porous media. Dynamics of fluids in fractured rock, pages 281-298, 2000.

P. C. Lichtner and Q. Kang. Upscaling pore-scale reactive transport equations using a multiscale continuum formulation. Water Resources Research, 43(12), 2007.

M. Löfgren and M. Sidborn. Statistical analysis of results from the quantitative mapping of fracture minerals in Laxemar: Site Descriptive ModellingComplementary Studies. R-09-31, Svensk Kärnbränslehantering AB (SKB), Stockholm, Sweden, 2009. 
M. Löfgren and M. Sidborn. Statistical analysis of results from the quantitative mapping of fracture minerals in Forsmark: Site descriptive modellingcomplementary studies. R-09-30, Svensk Kärnbränslehantering AB (SKB), Stockholm, Sweden, 2010.

J. Löfman and T. Karvonen. Simulations of Hydrogeological Evolution at Olkiluoto. POSIVA Working Report 2012-35, Posiva Oy, Helsinki, Finland., 2012.

K. MacQuarrie, K. Mayer, B. Jin, and S. Spiessl. The importance of conceptual models in the reactive transport simulation of oxygen ingress in sparsely fractured crystalline rock. Journal of Contaminant Hydrology, 112(1):64-76, 2010.

M. E. Malmström, G. Destouni, S. A. Banwart, and B. H. Strömberg. Resolving the scale-dependence of mineral weathering rates. Environmental Science $\&$ Technology, 34(7):1375-1378, 2000.

K. Mayer, E. Frind, and D. Blowes. Multicomponent reactive transport modeling in variably saturated porous media using a generalized formulation for kinetically controlled reactions. Water Resources Research, 38(9):13-1, 2002.

J. McMurry. Evaluating effects of deep recharge by a low-salinity, oxidizing groundwater: a geochemical modelling case study. Report No: 06819-REP-01300-10007R00, Ontario Power Generation, Nuclear Waste Management, 2000.

A. W. Miller, D. R. Rodriguez, and B. D. Honeyman. Upscaling sorption/desorption processes in reactive transport models to describe metal/radionuclide transport: A critical review. Environmental Science \& $T$ Technology, 44(21):7996-8007, 2010.

J. Molinero, P. Trinchero, H. Ebrahimi, L. de Vries, M. Luna, U. Svensson, and P. Lichtner. The BRIDGE project: Development, testing and application of a high performance computing framework for reactive transport modelling in crystalline roks (iDP). R-15-17, Svensk Kärnbränslehantering AB, Stockholm, Sweden, 2015.

D. L. Parkhurst and C. Appelo. User's guide to phreeqc (version 2): A computer program for speciation, batch-reaction, one-dimensional transport, and inverse geochemical calculations. 1999.

D. L. Parkhurst, K. L. Kipp, P. Engesgaard, and S. R. Charlton. Phast-a program for simulating ground-water flow, solute transport, and multicomponent geochemical reactions. Technical report, U.S. Geological Survey Techniques and Methods 6-A8, 2004.

Posiva Oy. Safety case for the disposal of spent nuclear fuel at olkiluoto. POSIVA report 2012-07, Posiva OY, Helsinki, Finland., 2012.

Posiva Oy. Olkiluoto site description 2011. POSIVA Report 2011-02, Posiva OY, Helsinki, Finland., 2013.

I. Puigdomenech, J. Ambrosi, L. Eisenlohr, J. Lartigue, S. Banwart, K. Bateman, A. Milodowski, J. West, L. Griffault, E. Gustafsson, K. Hama, H. Yoshida, S. Kotelnikova, K. Pedersen, V. Michaud, L. Trotignon, J. Rivas Perez, and E.-L. Tullborg. $\mathrm{O}_{2}$ depletion in granitic media. The REX project. TR-01-05, Svensk Kärnbränslehantering AB (SKB), Stockholm, Sweden, 2001.

N. Remy, A. Boucher, and J. Wu. Applied geostatistics with SGeMS: a user's guide. Cambridge University Press, 2009.

L. Romero, I. Neretnieks, and L. Moreno. Modelling of the Movement of the Redox Front in the Uranium Mine in Pocos de Caldas, Brazil. TR-90-39, Swedish Nuclear Fuel and Waste Management Co., Stockholm (Sweden), 1990. 
L. Romero, I. Neretnieks, and L. Moreno. Movement of the redox front at the Osamu Utsumi uranium mine, Poços de Caldas, Brazil. Journal of Geochemical Exploration, 45(1):471-502, 1992.

J. Salas, J. Molinero, I. Juarez, M. Gimeno, L. Auque, and J. Gomez. SRSite-hydrogeochemical evolution of the Forsmark site. TR-10-58, Svensk Kärnbränslehantering AB, Stockholm, Sweden., 2010.

M. Sidborn. Modelling long-term redox processes and oxygen scavenging in fractured crystalline rocks. Doctoral thesis, KTH School of Chemical Science and Engineering, Stockholm, Sweden, 2007.

M. Sidborn and I. Neretnieks. Long-term oxygen depletion from infiltrating groundwaters: Model development and application to intra-glaciation and glaciation conditions. Journal of Contaminant Hydrology, 100(1):72-89, 2008.

M. Sidborn, B. Sandstroem, E.-L. Tullborg, J. Salas, F. Maia, A. Delos, J. Molinero, L. Hallbeck, and K. Pedersen. Sr-site: Oxygen ingress in the rock at forsmark during a glacial cycle. TR-10-57, Svensk Kärnbränslehantering AB, Stockholm, Sweden, 2010.

SKB. Long-term safety for the final repository for spent nuclear fuel at forsmark: main report of the sr-site project. TR-11-01, Svensk Kärnbränslehantering AB, Stockholm, Sweden., 2011.

SKB. Site-descriptive modelling for a final repository for spent nuclear fuel in sweden. main report of the sr-site project. TR-11-01, Svensk Kärnbränslehantering AB, Stockholm, Sweden., 2013.

S. Spiessl, K. MacQuarrie, and K. Mayer. Identification of key parameters controlling dissolved oxygen migration and attenuation in fractured crystalline rocks. Journal of Contaminant Hydrology, 95(3):141-153, 2008.

S. Spiessl, K. Mayer, and K. MacQuarrie. Reactive transport modelling in fractured rock redox stability study. TR-2009-04, Nuclear Waste Management Organization NWMO. Toronto, Canada, 2009.

M. Stephan and J. Docter. JUQUEEN: IBM Blue Gene/Q Supercomputer System at the Jülich Supercomputing Centre. Journal of large-scale research facilities JLSRF, 1(http://dx.doi.org/10.17815/jlsrf-1-18), 2015.

W. Stumm and G. Lee. Oxygenation of ferrous iron. Industrial \& Engineering Chemistry, 53(2):143-146, 1961.

U. Svensson. A continuum representation of fracture networks. Part I: Method and basic test cases. Journal of Hydrology, 250(1):170-186, 2001a.

U. Svensson. A continuum representation of fracture networks. Part II: Application to the Äspö Hard Rock laboratory. Journal of Hydrology, 250(1):187-205, 2001b.

U. Svensson and M. Ferry. Darcytools: A computer code for hydrogeological analysis of nuclear waste repositories in fractured rock. Journal of Applied Mathematics and Physics, 2(06):365, 2014.

U. Svensson and S. Follin. Groundwater flow modelling of the excavation and operational phases-forsmark. R-09-19, Svensk Kärnbränslehantering AB, Stockholm, Sweden, 2010.

U. Svensson, H.-O. Kuylenstierna, and M. Ferry. DarcyTools version 3.4: concepts, methods and equations. R-07-38, Svensk Kärnbränslehantering AB (SKB), Stockholm, Sweden, 2010.

P. Trinchero, J. Molinero, G. Deissmann, U. Svensson, B. Gylling, H. Ebrahimi, G. Hammond, D. Bosbach, and I. Puigdomenech. Implications of grainscale mineralogical heterogeneity for radionuclide transport in fractured media. 
Transport in Porous Media, 1:73-90, 2017a. doi: 10.1007/s11242-016-0765-0.

616 P. Trinchero, I. Puigdomenech, J. Molinero, H. Ebrahimi, B. Gylling, U. Svensson, D. Bosbach, and G. Deissmann. Continuum-based DFN-consistent numerical framework for the simulation of oxygen infiltration into fractured crystalline rocks. Journal of Contaminant Hydrology, 200:60-69, 2017b. doi: 10.1016/j.jconhyd.2017.04.001.

21 P. Vidstrand, S. Follin, and N. Zugec. Groundwater flow modelling of periods with periglacial and glacial climate conditions-Forsmark. R-09-21, Swedish Nuclear Fuel and Waste Management Co., Stockholm (Sweden), 2010.

${ }_{624}$ M. Willmann, J. Carrera, and X. Sánchez-Vila. Transport upscaling in hetero${ }_{625}$ geneous aquifers: What physical parameters control memory functions? Water ${ }_{626}$ Resources Research, 44(12):W12437, 2008. 


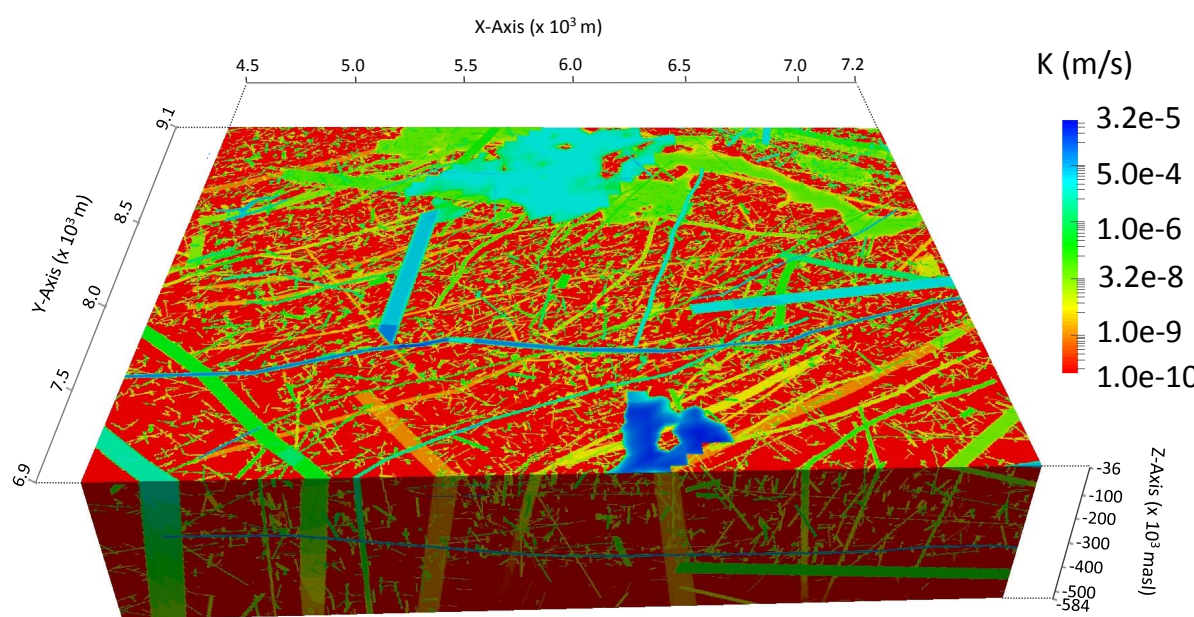

Fig. 1 Hydraulic conductivity field for the Forsmark spent fuel repository area generated by DarcyTools (figure taken from Molinero et al. (2015)). X and Y are local coordinates, whereas $\mathrm{Z}$ is expressed as meters above sea level (masl).

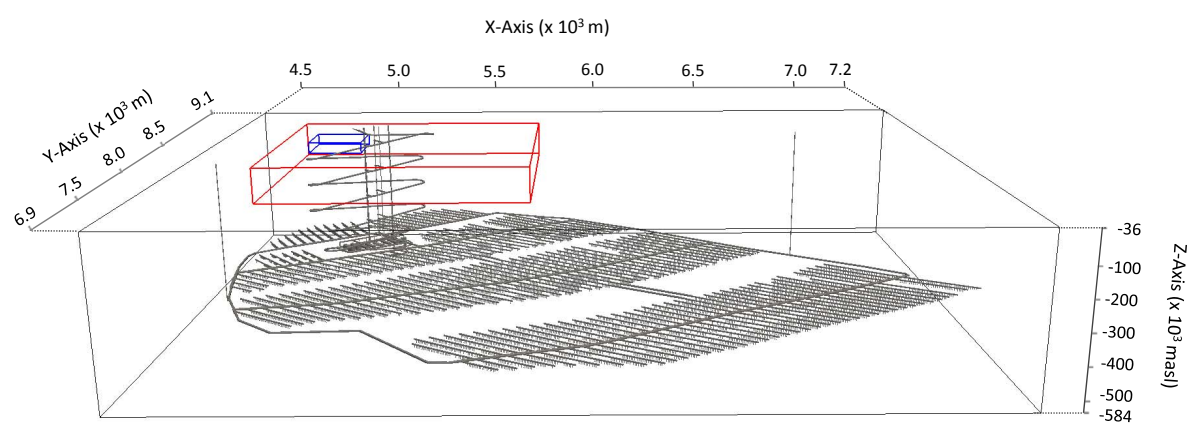

Fig. 2 View of the Forsmark spent fuel repository area (gray box) and the two sub-domains (sub-domain 1: blue; sub-domain 2: red) used in the reactive transport simulations. The layout of the repository and access tunnels is shown for illustrative purposes. 
1

2

3

4

5

6

7

8

9

10

11

12

13

14

15

16

17

18

19

20

21

22

23

24

25

26

27

28

29

30

31

32

33

34

35

36

37

38

39

40

41

42

43

44

45

46

47

48

49

50

51

52

53

54

55

56

57

58

59

60

61

62

63

64

65

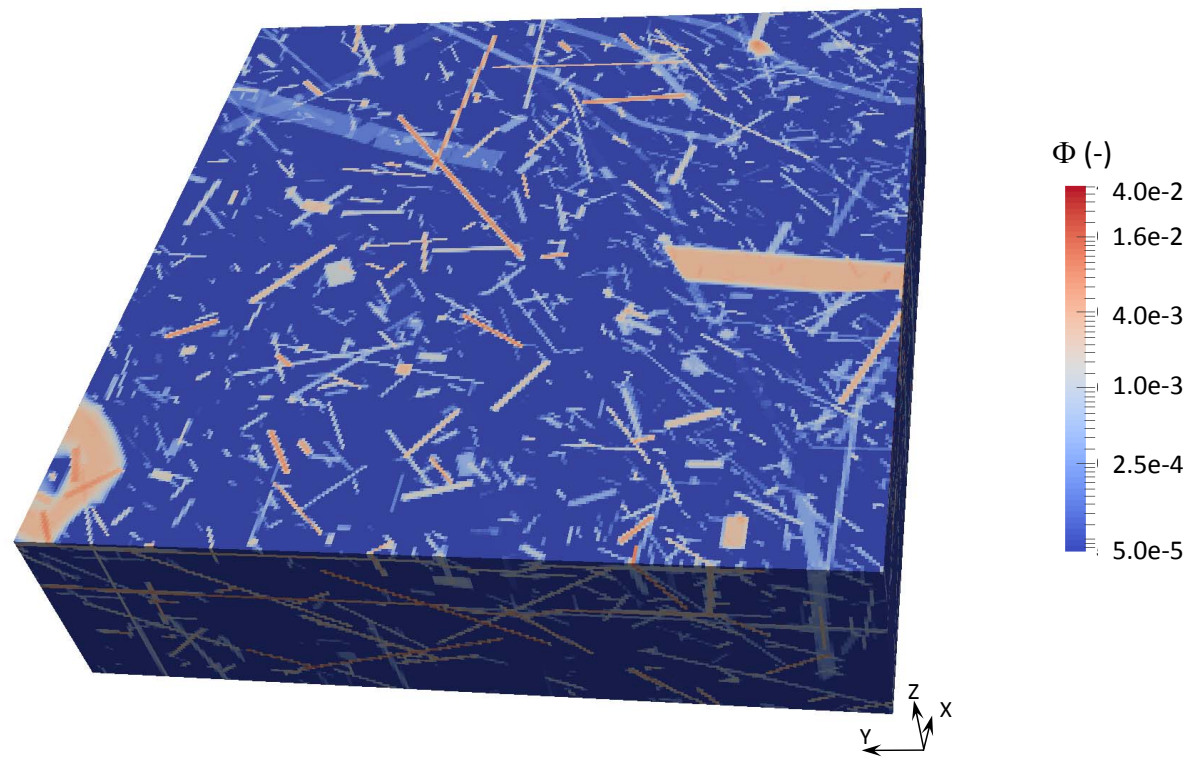

Fig. 3 Porosity plotted over sub-domain 2.
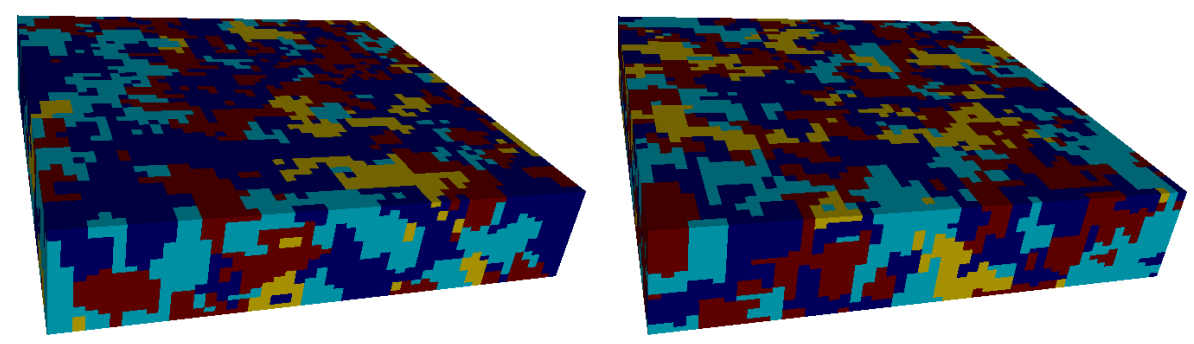

Fig. 4 Sub-domain 1: two different realizations with heterogeneous distribution of biotite (left: realization 1; right: realization 8 ). Dark blue: volume fraction equal to 0.1 ; light blue: volume fraction equal to 0.01; yellow: volume fraction equal to 0.001 ; red: biotite absent.
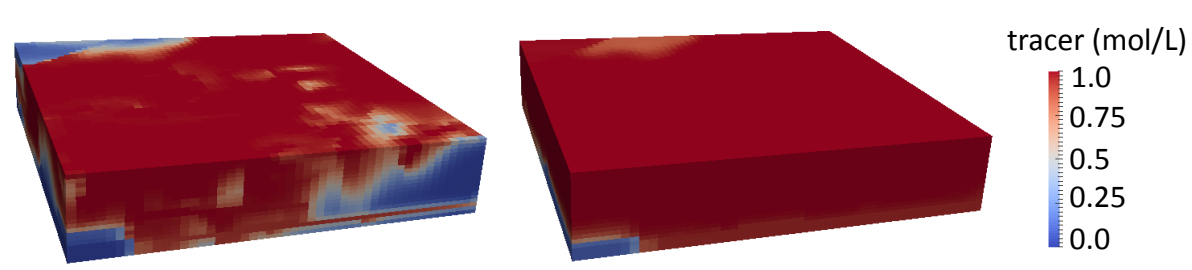

Fig. 5 Sub-domain 1. Tracer concentration (a) at 50 years and (b) 1000 years. 
1

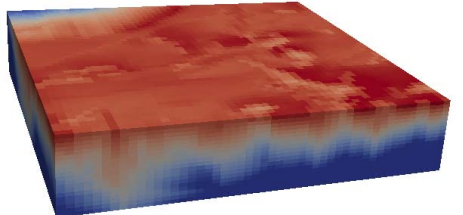

(a) homogeneous; $\mathrm{t}=50 \mathrm{y}$.

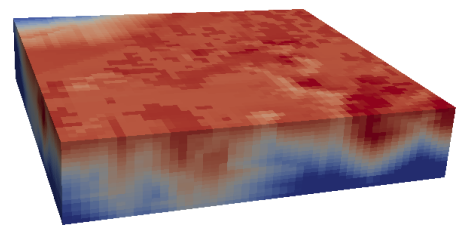

(c) R1; t $=50 \mathrm{y}$.

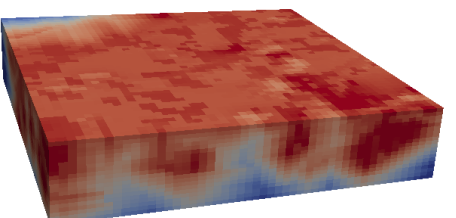

(e) $R 8 ; t=50 y$.

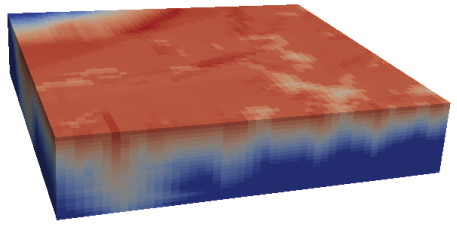

(b) homogeneous; $\mathrm{t}=1000 \mathrm{y}$.

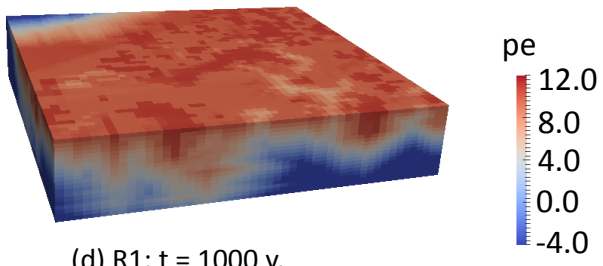

(d) R1; t $=1000 \mathrm{y}$

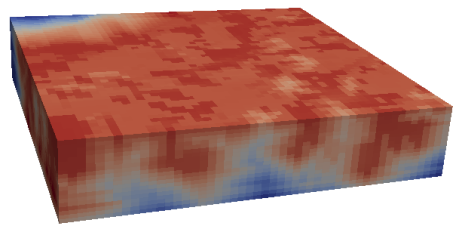

(f) $R 8 ; t=1000 y$.

Fig. 6 Sub-domain 1. pe at different simulations times computed for the homogeneous case and for the heterogeneous realizations $\mathrm{R} 1$ and $\mathrm{R} 8$.

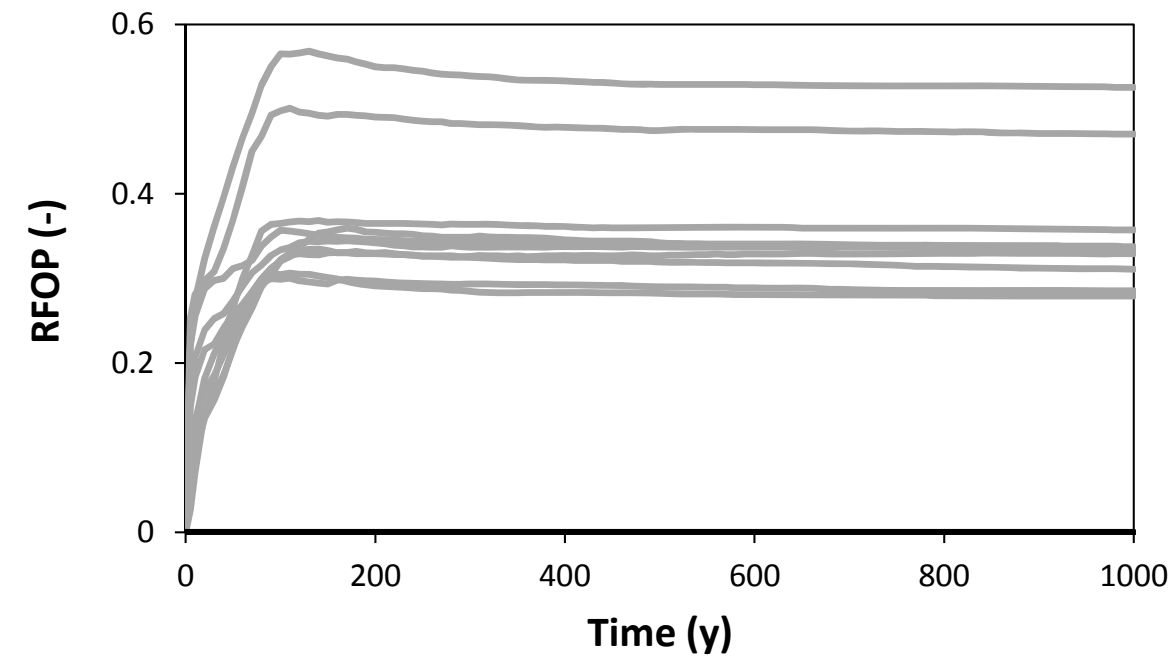

Fig. 7 Sub-domain 1. Relative footprint of the oxidizing plume computed at the bottom side of the domain (40 m depth) for a threshold pe of 2.0 and for the ten stochastic realizations (grey lines). In the homogeneous model pe is always below the threshold. 
1

2

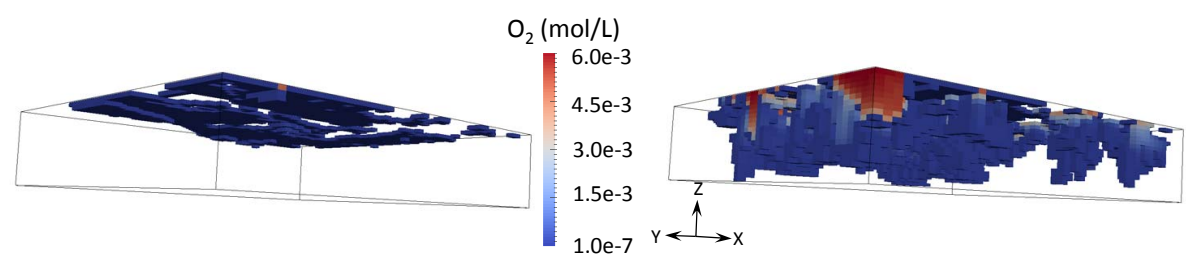

Fig. 8 Sub-domain 1. Oxygen concentration at time 1,000 y for (left) the homogeneous case and (right) the heterogeneous realization R8. The cells with oxygen concentration lower than $1 \cdot 10^{-7}$ are not shown.

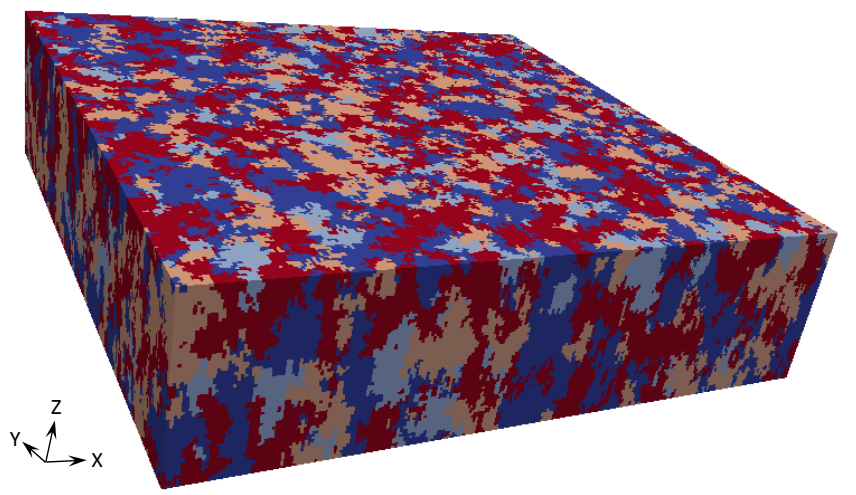

Fig. 9 Sub-domain 2: single realization of heterogeneous distribution of biotite. Red: volume fraction equal to 0.1 ; salmon: volume fraction equal to 0.01 ; light blue: volume fraction equal to 0.001 ; dark blue: biotite absent. Vertical exaggeration of $2: 1$ is used. 


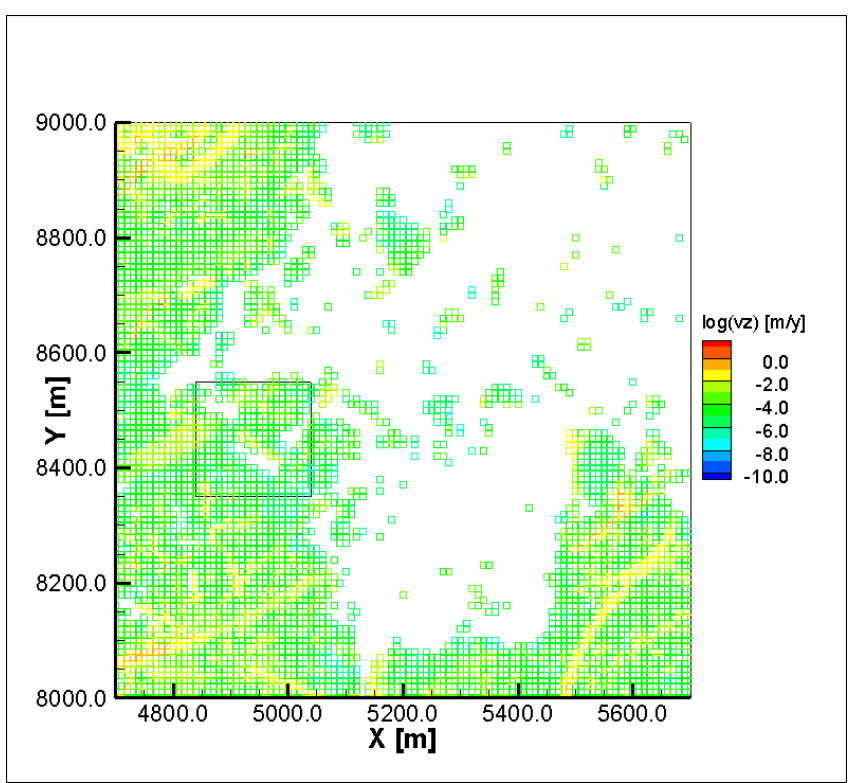

Fig. 10 Vertical component of Darcy's velocity in the upper layer of sub-domain 2. Only the grid cells with negative velocity direction (i.e. downward fluxes) are shown. The small square indicates the extension and location of sub-domain 1.
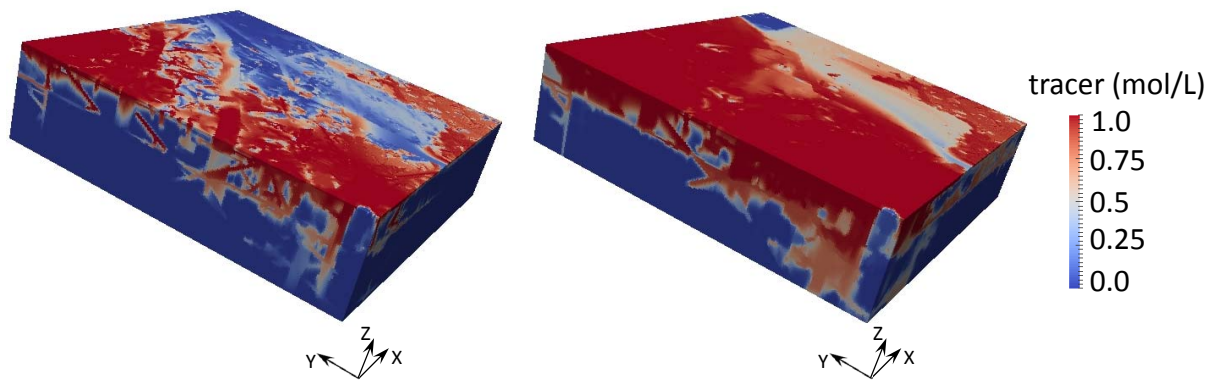

Fig. 11 Sub-domain 2. Tracer concentration at time (left) $10 \mathrm{y}$ and (right) $70 \mathrm{y}$. Vertical exaggeration of $2: 1$ is used. 

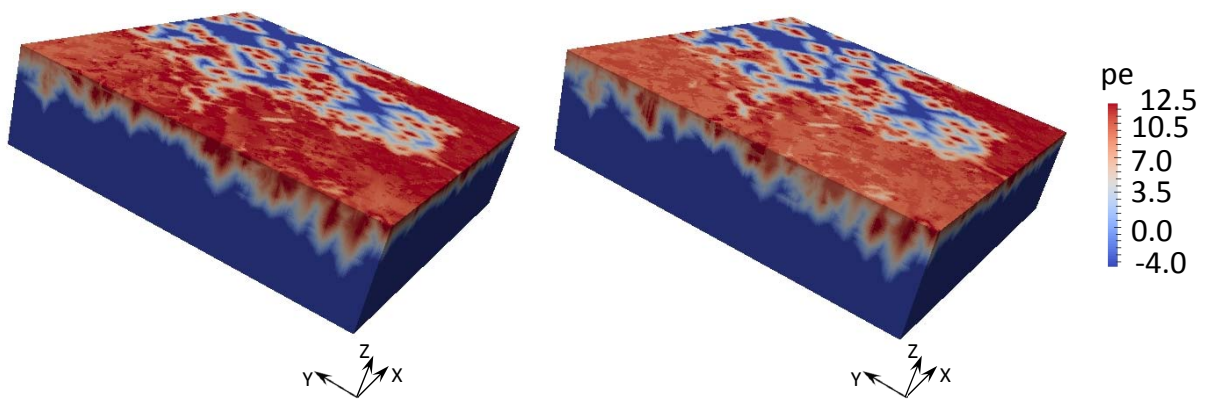

Fig. 12 Sub-domain 2. pe distribution at time (left) $10 \mathrm{y}$ and (right) $70 \mathrm{y}$. Vertical exaggeration of $2: 1$ is used.

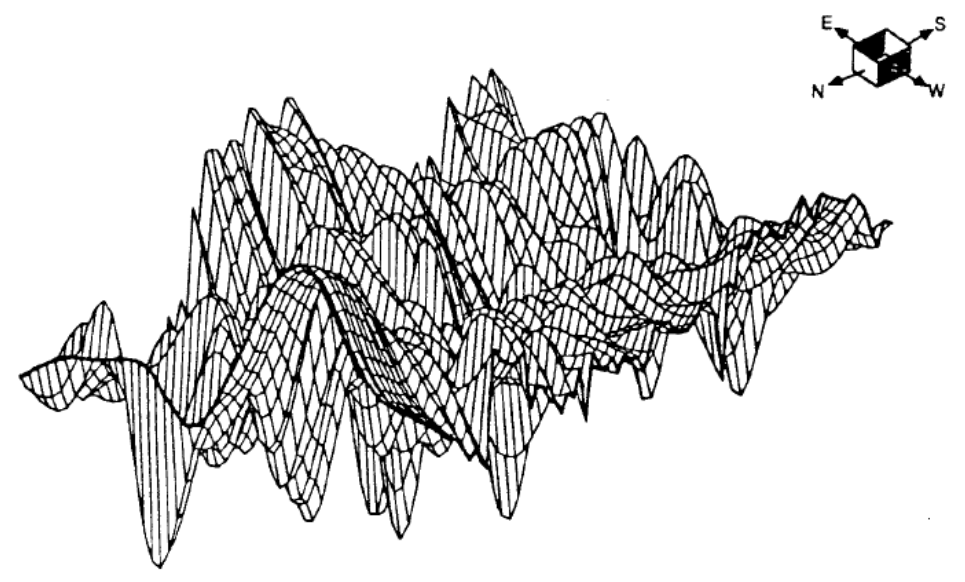

Fig. 13 A 3D-view of oxidized fingers at the Osamu Utsumi mine at Poços de Caldas, Brazil. The depth of the fingers varies between 0 and $200 \mathrm{~m}$ in an area of $600 \mathrm{~m} \times 300 \mathrm{~m}$. Reprinted from Romero et al. (1992), with permission from Elsevier.

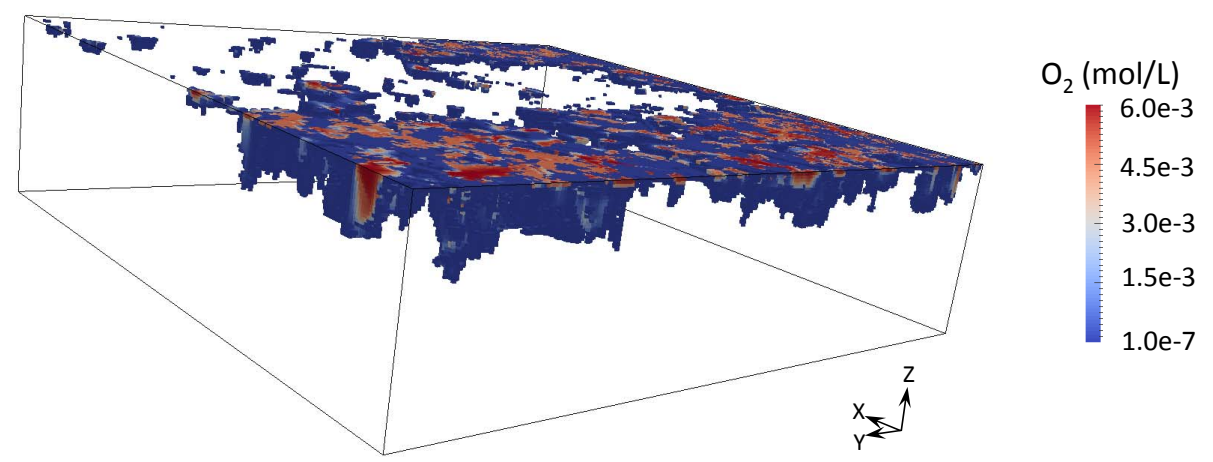

Fig. 14 Sub-domain 2. Oxygen concentration at time 70 y. The cells with oxygen concentration lower than $1 \cdot 10^{-7}$ are not shown. 
1
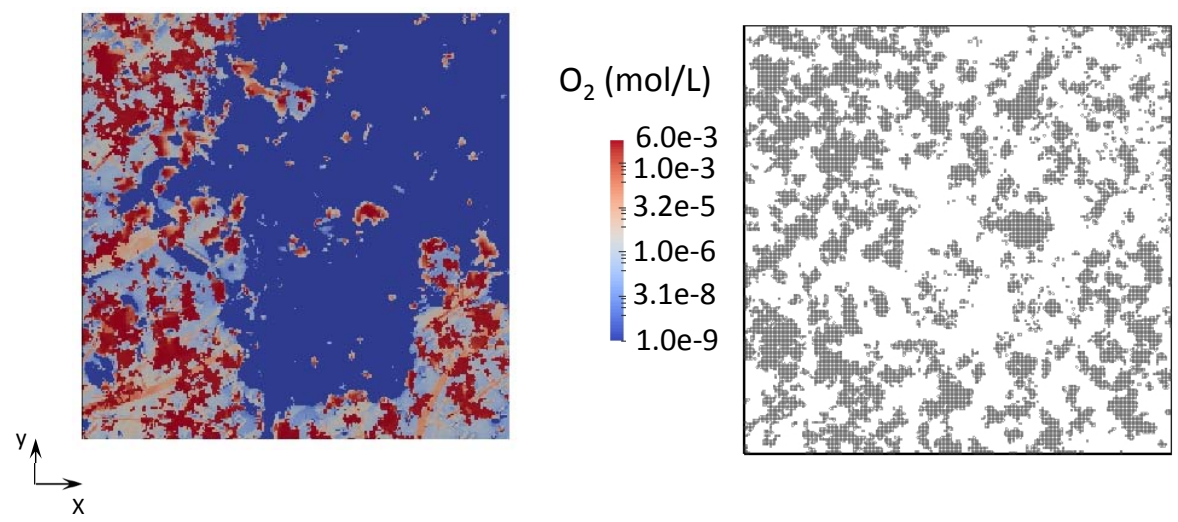

Fig. 15 Sub-domain 2. (left) Oxygen concentration in the upper layer of sub-domain 2 at 70 $\mathrm{y}$ of simulation time and (right) cells of the upper boundary (shaded in gray) where biotite is absent.

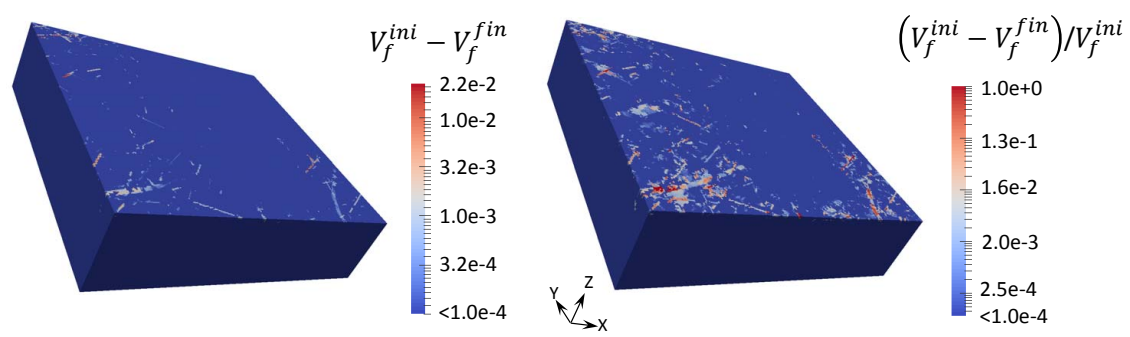

Fig. 16 Sub-domain 2. Dissolution of biotite at $70 \mathrm{y}$ of simulation time expressed as (left) absolute and (right) relative difference in biotite volume fraction. 